\title{
A retrospective, observational, epidemiological study of meningococcal meningitis cases in the UK in relation to the change in smoking legislation
}

H Preston

From International Conference for Healthcare and Medical Students 2011

Dublin, Ireland. 4-5 November 2011

\section{Introduction}

Neisseria Meningitidis is the greatest risk to young adults for fatal meningitis. It has been seen in other studies that smokers carry an increased amount of this bacteria and can be carriers for the infection. The aim of the study is to determine whether the smoking legislation brought into the UK has had an effect on the case numbers of meningococcal meningitis, as smoking in seen as a risk factor.

\section{Methods}

Data was obtained from HPS and HPA to get national figures over a decade spanning the smoking ban legislation.

\section{Results}

Results show that there has not been a dramatic decline in cases of meningococcal meningitis since the introduction of the smoking ban.

\section{Conclusions}

There should be continued surveillance in the future to see if a there is a long term trend with rates of meningococcocal meningitis cases.

Published: 9 July 2012

\section{doi:10.1186/1753-6561-6-S4-P26}

Cite this article as: Preston: A retrospective, observational,

epidemiological study of meningococcal meningitis cases in the UK in relation to the change in smoking legislation. BMC Proceedings 20126

(Suppl 4):P26.

University of Edinburgh, UK

\section{Biomed Central

(0) 2012 Preston; licensee BioMed Central Ltd. This is an Open Access article distributed under the terms of the Creative Commons Attribution License (http://creativecommons.org/licenses/by/2.0), which permits unrestricted use, distribution, and reproduction in any medium, provided the original work is properly cited.
Submit your next manuscript to BioMed Central and take full advantage of:

- Convenient online submission

- Thorough peer review

- No space constraints or color figure charges

- Immediate publication on acceptance

- Inclusion in PubMed, CAS, Scopus and Google Scholar

- Research which is freely available for redistribution 